\title{
Umezakia natans M.WATAN. does not belong to Stigonemataceae but to Nostocaceae
}

\author{
Yuko NiIYAMA $^{1}$, Akihiro TujI ${ }^{1} \&$ Shigeo TsuJIMURA ${ }^{2}$ \\ ${ }^{1}$ Department of Botany, National Museum of Nature and Science, 4-1-1 Amakubo, Tsukuba, Ibaraki 305-0005, \\ Japan; e-mail:3ken@kahaku.go.jp \\ ${ }^{2}$ Lake Biwa Environmental Research Institute, 5-34 Yanagasaki, Otsu, Shiga 520-0022, Japan
}

\begin{abstract}
Umezakia natans M.WATAN. was described by Dr. M. Watanabe in 1987 as a new species in the family of Stigonemataceae, following the rules of the Botanical Code. According to the original description, this planktonic filamentous species grows well in a growth media with $\mathrm{pH}$ being 7 to 9 , and with a smaller proportion of sea water. Both heterocytes and akinetes were observed, as well as true branches developing perpendicular to the original trichomes in cultures older than one month. Watanabe concluded that Umezakia was a monotypic and only planktonic genus belonging to the family of Stigonemataceae. Unfortunately, the type culture has been lost. In 2008, we successfully isolated a new strain of Umezakia natans from a sample collected from Lake Suga. This lake is situated very close to the type locality, Lake Mikata in Fukui Prefecture, Japan. We examined the morphology of this $U$. natans strain, and conducted a DNA analysis using $16 \mathrm{~S}$ rDNA regions. Morphological characters of the newly isolated strain were in a good agreement with the original description of $U$. natans. Furthermore, results of the DNA analysis showed that $U$. natans appeared in a cluster containing Aphanizomenon ovalisporum and Anabaena bergii. Therefore we conclude that Umezakia natans belongs to the family of Nostocaceae, not to Stigonemataceae.
\end{abstract}

Key words: Anabaena bergii, Aphanizomenon ovalisporum, Nostocaceae, Stigonemataceae, Umezakia natans, $16 \mathrm{~S}$ rDNA

\section{Introduction}

In 1984, late Dr. Masayuki Watanabe found some slender trichomes in net samples collected from Lake Mikata in Mikata Five Lakes Region, Fukui Prefecture, Japan (Fig. 1; site A), and isolated them (Watanabe 1987, 2007). He writes in his articles that the isolated trichomes are superficially similar to Raphidiopsis mediterranea SKuJA f. major YoNEDA, but both heterocytes and akinetes are observed in the cultured strain, and in one month old cultured strain with lower proportions of sea water the trichomes begin to rise on one side and the true branches develop perpendicular to the original trichomes. On the basis of these observations, he concludes this alga is a new and the only planktonic species belonging to Stigonemataceae and describes Umezakia natans M.WATAN. after Dr. Isamu Umezaki (WatanABE 1987, 2007). Unfortunately, the type culture, TAC 101 , has been lost before 2002 in our laboratory. Dr. M. Watanabe and we had collected some samples from the type locality, Lake Mikata, and many other lakes and ponds in Japan, but we could not find out any thallus of Umezakia natans for more than 20 years. In 2008, S. Tsujimura collected some samples from Lake Suga in Mikata Five Lakes Region (Fig. 1; site B) and succeeded to isolate $U$. natans.

Results of the morphological observations and 16S rDNA analysis of the newly cultivated strain are reported here.

\section{Materials and Methods}

Cultured strains. Isolation was done by the pipette washing method under a binocular using CT medium (IChimura \& Watanabe 1977). Then $10 \mathrm{ml}$ of modified C medium (Ichimura \& Watanabe 1977) contained in a screw cap test tube was used for maintenance of strain. Modified $\mathrm{C}$ medium was adjusted to $\mathrm{pH} 7.5$ buffering with HEPES instead of Tris (hydroxymethyl) aminomethan. The cultured strain was illuminated by cool-white fluorescent lamps, with a photon flux 
Table 1. Accession numbers, species names and strain numbers of strains used in this study.

\begin{tabular}{|c|c|c|}
\hline Accession No. & Species name & Strain No. \\
\hline AJ630458.1 & Anabaena augstumalis & SCMIDKE \\
\hline FJ234890.1 & Anabaena bergii & ANA366B \\
\hline FJ234897.1 & Anabaena bergii & ANA283A \\
\hline FM177481.1 & Anabaenopsis nadsonii & 2LT27S11 \\
\hline AY038033.1 & Anabaenopsis sp. & PCC 9215 \\
\hline AJ293129.1 & Aphanizomenon flos-aquae & PMC 9706 \\
\hline AJ293130.1 & Aphanizomenon flos-aquae & PMC 9707 \\
\hline AJ293126.1 & Aphanizomenon flos-aquae & PMC 9401 \\
\hline AJ293127.1 & Aphanizomenon gracile & PMC 9402 \\
\hline AY196087.1 & Aphanizomenon issatschenkoi & TAC419 \\
\hline FM177485.1 & Aphanizomenon ovalisporum & 1LT27S04 \\
\hline EU076457.1 & Aphanizomenon ovalisporum & FAS-AP1 \\
\hline AY038036.1 & Cyanospira rippkae & PCC 9501 \\
\hline AB551466.1 & Dolichospermum akankoensis & TAC505 \\
\hline AM230704.1 & Gloeotrichia echinulata & PYH14 \\
\hline AJ133177.1 & Nodularia baltica & BY1 \\
\hline AJ781145.1 & Nodularia harveyana & BECID27 \\
\hline AJ781149.1 & Nodularia sphaerocarpa & BECID35 \\
\hline AJ781131 .1 & Nodularia spumigena & PCC 9350 \\
\hline AF268012.1 & Nodularia spumigena & NSBL05 \\
\hline GQ167549.1 & Nostoc calcicola & 99 \\
\hline AJ630451.1 & Nostoc muscorum & I \\
\hline AB087403.2 & Nostoc sp. & KU001 \\
\hline GQ259207.1 & Nostoc sp. & CENA88 \\
\hline AB093486.1 & Tolypothrix sp. & IAM M-259 \\
\hline AJ630457.1 & Trichormus variabilis & GREIFSWALD \\
\hline DQ234830.1 & Trichormus variabilis & KCTC AG10026 \\
\hline AB608023.1 & Umezakia natans & TAC611 \\
\hline
\end{tabular}

density of ca. $30 \mu \mathrm{mol} . \mathrm{m}^{-2} \cdot \mathrm{sec}^{-1}$, photoperiod of L/D = $8 / 16$ hours, and a temperature of $18^{\circ} \mathrm{C}$. Morphological observations were performed for the cultured strain with the light microscope.

DNAextraction and amplification. DNA was extracted using GenomicPrep (Amersham Biosciences, NJ) from cultured strain. PCR of $16 \mathrm{~S}$ rDNA was performed with prokaryote universal primers: forward primer 8f (LANE 1991) and primer 1480 for heterocytous cyanobacteria (GUGGER et al. 2002) using a thermal cycler (iCycler) with Ex Taq DNA polymerase (Takara, Tokyo, Japan). PCR products were purified with ExoSAP-IT (USB Corporation, Cleveland, OH, USA) following the instruction manual. The cycle sequencing samples were purified by ethanol precipitation. Sequencing was conducted using an ABI PRISM 3130xl Genetic Analyzer (Applied Biosystems). The obtained sequences were assembled using Chromas PRO (Technelysium Pty Ltd, Tewantin, Australia).

Two 16S rDNA sequences of Umezakia natans using TAC101 deposited in the GenBank, AF516748.1 and AY897614.1, were also discussed.

Phylogenetic reconstruction. The Basic Local Alignment Search Tool (BLAST) at NCBI (http:// blast.ncbi.nlm.nih.gov/Blast.cgi) and some data of our own heterocytous cyanobacteria strains (WATANABE et al. 2004, TUJI \& NIIYAMA 2010) were used for finding similar 16S rDNA sequences with the sequence of Umezakia natans. Phylogenetic and molecular evolutionary analyses for obtained sequences were conducted using MEGA computer program (TAMURA et al. 2007). Alignments were checked manually. 


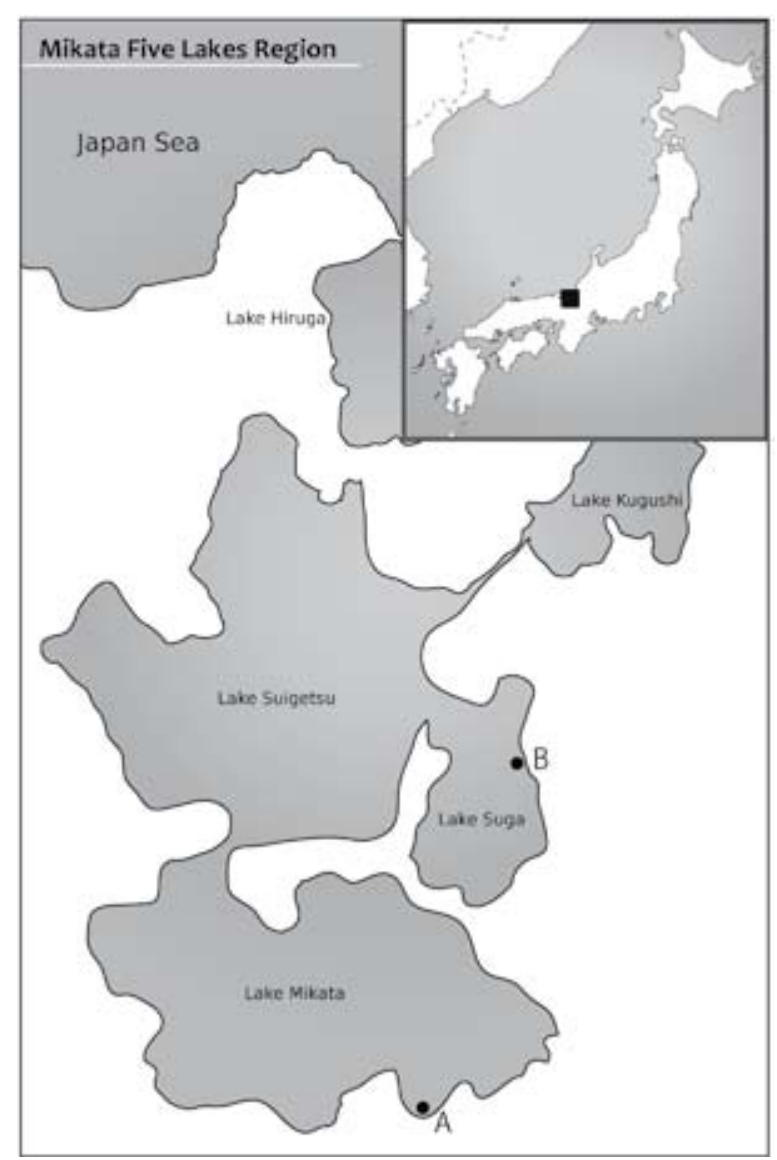

Fig. 1. Site map of localities of Umezakia natans in Mikata Five Lakes Region, Fukui Prefecture, Japan. (A) Lake Mikata; (B) Lake Suga.

Maximum Likelihood (ML) tree was calculated using the software with the best fits model $(\mathrm{GTR}+\mathrm{I}+\mathrm{G})$ by AICc scores (Akaike Information Criterion, corrected) and the substitution nucleotide matrix parameters calculated by the software. Five hundreds bootstrap were generated. Bootstrap values using neighborjoining $(\mathrm{NJ})$ method are also calculated.

\section{Results and Discussion}

Original description of Umezakia natans M.Watan. is as follows (Watanabe 1987): Filaments solitary, free floating, straight or slightly curved, sometimes with true branches, with a thick mucilaginous sheath; trichomes attenuated at the ends, constricted or not constricted at the cross walls, 50-3,000 $\mu \mathrm{m}$ long, (4-)5-7(-8) $\mu \mathrm{m}$ wide, at the apical part $2.5-3.5 \mu \mathrm{m}$ wide; cells with gas vacuoles, apical cells with few or no gas vacuoles, cylindrical, barrel-shaped or ellipsoidal, $(0.5-) 1-2(-3)$ times as long as wide; heteocytes usually scarce but frequently occurring in nitrogen deficient environments, spherical to elongate, 6-8 $\mu \mathrm{m}$ wide, $7-9 \mu \mathrm{m}$ long; akinetes one to several in series, ellipsoidal, thick-walled with a smooth surface, $7.4-11.0 \mu \mathrm{m}$ wide, $10.5-18.7 \mu \mathrm{m}$ long.

Although the newly isolated trichome was a short filament with only vegetative cells, we could observe both heterocytes and akinetes in the cultured trichomes (Fig. 2). Many but not all the trichomes are constricted at the cross walls and some of them attenuate at the ends while others do not attenuate and slightly elongate to be conical (Figs. 2, 3), with some swollen cells which sometimes produce short $\mathrm{T}$-shaped branchings (Fig. 4). Cells are with gas vacuoles, cylindrical, spherical or ellipsoidal, $3-9 \mu \mathrm{m}$ wide $(5.8 \pm 1.6$ $\mu \mathrm{m} ; \mathrm{n}=34)$ and $4-10 \mu \mathrm{m}$ long $(6.8 \pm 1.9 \mu \mathrm{m} ; \mathrm{n}=34)$, at the apical part 2.5-4 $\mu \mathrm{m}$ wide, apical cells are sometimes hyaline. Swollen cells are 7-14 $\mu \mathrm{m}$ wide $(10.3 \pm 2.5 \mu \mathrm{m} ; \mathrm{n}=10)$ and $8-23 \mu \mathrm{m}$ long $(18.0 \pm 4.8 \mu \mathrm{m} ; \mathrm{n}=10)$. Heterocytes are scarce but frequently in old cultures, spherical, intercalary (Fig. 2), 5-8 $\mu \mathrm{m}$ wide $(6.8 \pm 1.0 \mu \mathrm{m} ; \mathrm{n}=21), 5.5-8$ $\mu \mathrm{m}$ long (mean $=7.1 \pm 0.7 \mu \mathrm{m} ; \mathrm{n}=21$ ). Akinetes are very scarce, ellipsoidal, $7-8 \mu \mathrm{m}$ wide $(7.8 \pm 0.5 \mu \mathrm{m}$; $\mathrm{n}=4), 8-14 \mu \mathrm{m}$ long $(10.5 \pm 3.0 \mu \mathrm{m} ; \mathrm{n}=4)$, distant from heterocytes (Fig. 2). These morphological characters are in good agreement with the original description.

Two 16S rDNA sequences of Umezakia natans are deposited in the GenBank. The first one is 1433bp (AF516748.1) and the next one is 910 bp (AY897614.1). Though both sequences use the same strain (TAC101), 71bp differences (about $8 \%$ ) are found in their 910bp. Differences are also seen in conserved regions of $16 \mathrm{~S}$ rDNA of Cyanobacteria between them. The sequence of AY897614.1 is more similar to the sequence of TAC611 in this study (20bp differences in 910bp) than AF516748.1. Since these differences are not normal in a same strain, these sequences and/ or strain TAC101 should have contamination or some problems on it and we omit these sequences for the following discussion.

Figure 5 shows the phylogenetic position of Umezakia natans (TAC611) and related taxa with Maximum Likelihood (ML) method from 16S rDNA. Accession and strain numbers and species names are listed in Table 1. The strain of $U$. natans shares a high 16S rDNA sequence similarity and clusters with Aphanizomenon ovalisporum FORTI and Anabaena bergii Ostenfeld strains. So it is concluded that Umezakia natans does not belong to Stigonemataceae but to Nostocaceae. 


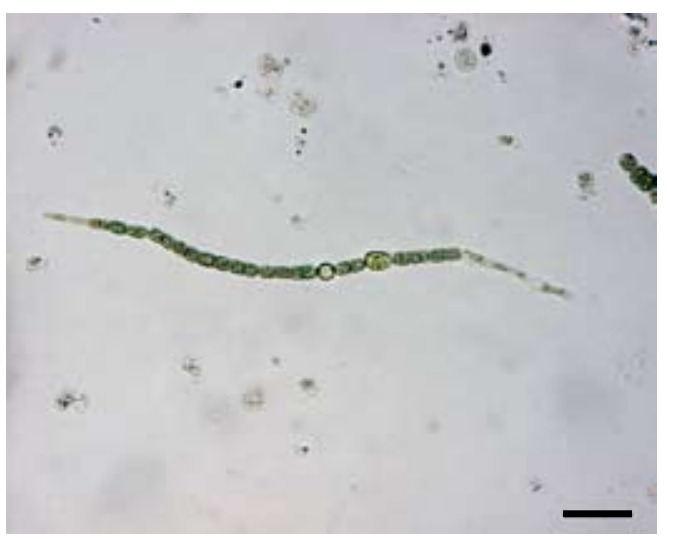

Fig. 2. A trichome of Umezakia natans (TAC 611) with an akinete and a heterocyte. Its apical cells attenuate. Scale bar $30 \mu \mathrm{m}$.

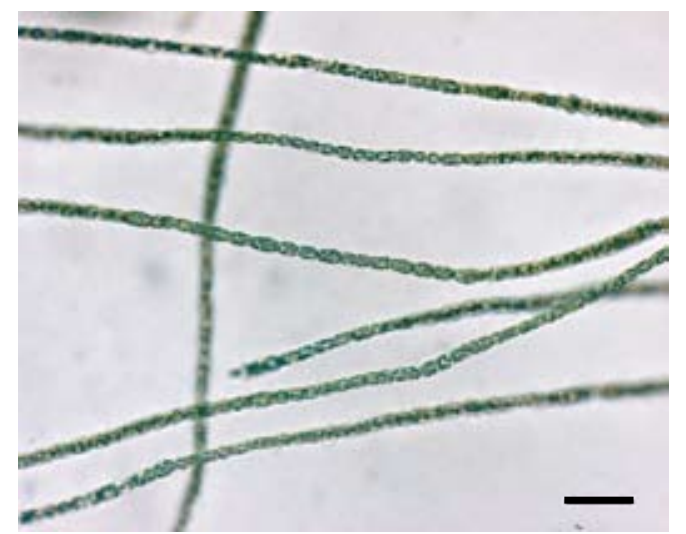

Fig. 3. Long trichomes of Umezakia natans (TAC 611) consisting of only vegetative cells. Scale bar $30 \mu \mathrm{m}$.

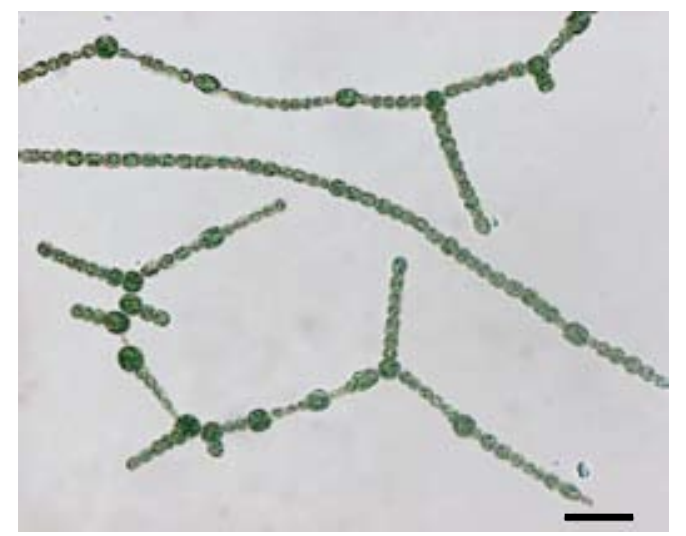

Fig. 4. Three trichomes of Umezakia natans (TAC 611). One trichome (middle one) are constricted at the cross walls and without any branchings. Other two have some swollen cells and branchnings. Scale bar $30 \mu \mathrm{m}$.
Furthermore, this cluster is different from any other clusters containing traditional Anabaena or Aphanizomenon strains (RAJANIEMI et al. 2005b, STÜKEN et al. 2009, ZAPOMĔLOVÁ et al. 2009, 2010, Komérek 2010, TuJI \& NiIYAMA 2010). Dolichospermum Clusters A and B, and Sphaerospermopsis Cluster D described in Fig. 5 correspond to Anabaena Clusters A, B and D, respectively in TuJI \& Niryama (2010). Dolichospermum mendotae and D. lemmermannii in Fig. 5 is included in Anabaena Cluster C, and D. akankoensis is included in Cluster $\mathrm{C}^{\prime}$ in TuJI \& NiIYAMA (2010). STüKEN et al. (2009) describes four groups by analysis of DNA sequence similarities of three different gene fragmentations. Their Group IV comprises Ap. ovalisporum and $A n$. bergii strains, and all strains in this group produce Cylindrospermopsin. U. natans is also known to produce Cylindrospermopsin (HARADA et al. 1994). STüKEN et al. (2009) describes, however, non-Cylindrospermopsin producing $A n$. bergii strains are within other two clusters. One of these clusters (Group II in STüKEN et al. 2009) apparently comprises Sphaerospermopsis species (ZAPOMĔLOVÁ et al. 2009, 2010, KOMÁReK 2010, TuJI \& NiIYAma 2010).

It is often pointed out that An. bergii and Ap. ovalisporum are morphologically very similar (KomÁrek 1958; KomấreK \& KovÁČIK 1989; Pollinger et al. 1998; GKelis et al. 2005; Komárek \& KomÁrková 2006; StüKEn et al. 2009). They are solitary, free floating, have straight to slightly curved trichomes with attenuated ends, intercalary spherical to elliptical heterocytes, and elliptical to broadly oval akinetes, which are usually intercalary and distant from heterocytes. Only U. natans has a tendency to produce branchings and seems to have bifacial morphological characteristics of $A n$. bergii and Ap. ovalisporum. That is, many but not all the trichomes of $U$. natans are constricted at the cross walls and some of them attenuate at the ends while others do not attenuate and slightly elongate to be conical (Figs. 2, 3). The morphology of its vegetative cells is various, e.g. cylindrical, spherical, barrel-shaped or ellipsoidal.

It was already proved by the morphological and ecological characteristics and molecular sequencings that the genera Anabaena and Aphanizomenon must be classified only in the sense of the type species Anabaena oscillarioides Bory ex Bornet et Flahault 1886 and Aphanizomenon flos-aquae RALFs ex BORNET et Flahault 1888, respectively (Rajaniemi et al. 


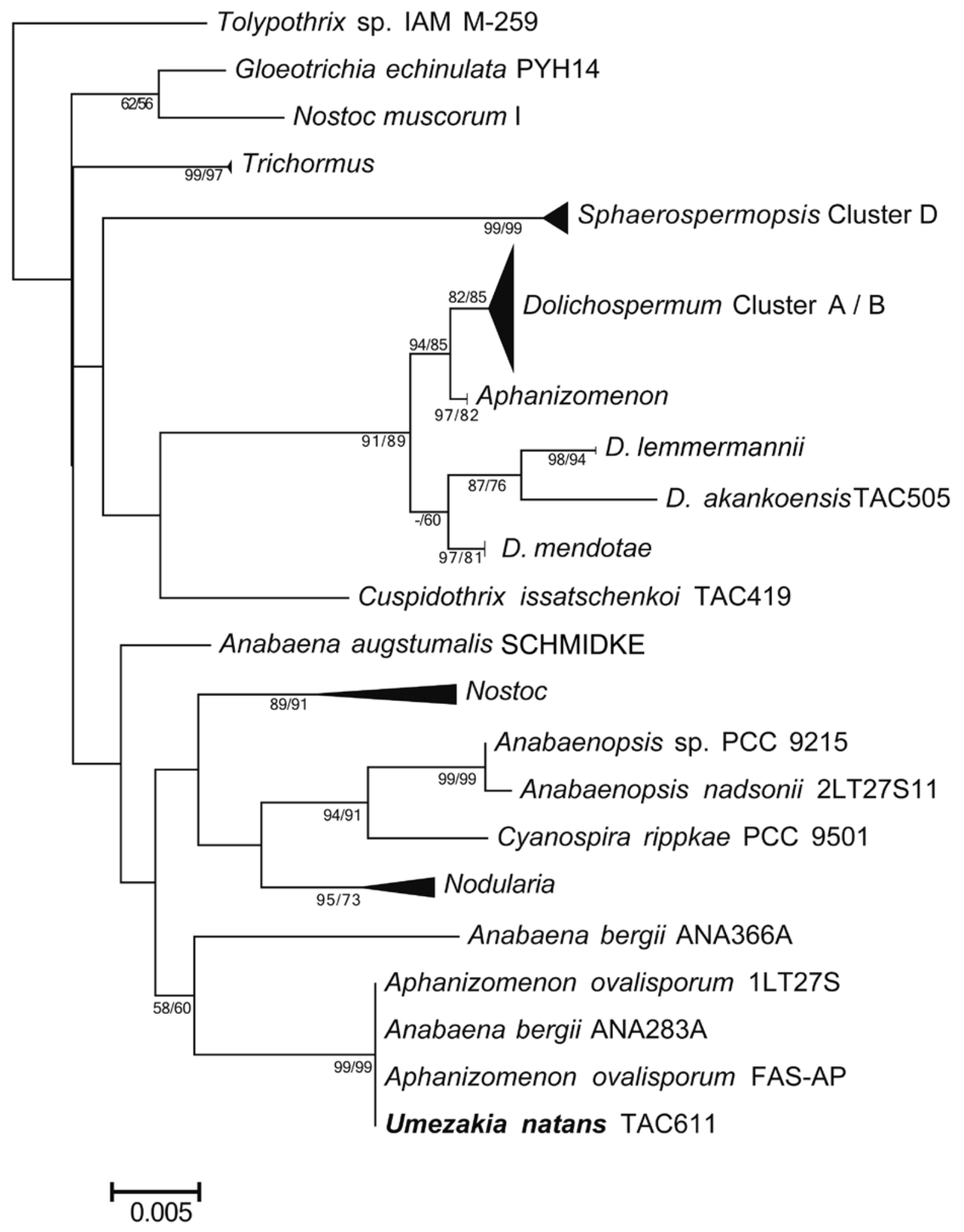

Fig. 5. Phylogenetic position of Umezakia natans (TAC611) and related taxa with Maximum Likelihood (ML) method from 16S rDNA. Accession numbers are listed on Table 1. Numbers at branches indicate NJ (Neighbour Joining)/ML bootstrap support values (only values higher than 60 are shown).

Trichormus cluster includes T. variabilis GREIFSWALD and T. variacilis KCTC AG10026. Dolichospermum Clusters A and B, and Sphaerospermopsis Clusters D correspond to Anabaena Clusters A, B and D, respectively in TuJI \& NIIYAMA (2010). Aphanizomenon cluster includes Ap. flos-aquae PMC 9401, Ap. gracile PMC 9402 and Ap. flos-aquae PMC 9707. D. lemmermannii includes TAC437and TAC438. D. mendotae cluster includes Ap. flos-aquae PMC 9706, D. mendotae TAC583 and TAC584. Nostoc cluster includes Nostoc calcicola 99, Nostoc sp. KU001 and Nostoc sp. CENA88. Nodularia cluster includes $N$. baltica BY1, N. harveyana BECID27, N. sphaerocarpa BECID35, N. spumigena PCC 9350 and N. spumigena NSBL05. 
2005a; KomÁreK \& KomÁrKová 2006; WaCKLIN et al. 2009; KомÁreк 2010). The traditional genus Anabaena is now divided into benthic Anabaena and Trichormus (type species: T. variabilis (Kütz. ex Bornet et Flahault) Kom. et Anagn. 1989), and planktonic Dolichospermum (type species: D. flos-aquae (BréB. ex Bornet et Flahault) Wacklin, Hoffmann et Kom. 2009) and Sphaerospermopsis (type species: S. reniformis (Lemmerm.) Zapomělová, Jezberová, Hrouzek, Hisem, Řeháková et KomÁrková 2009). Traditional genus Aphanizomenon is now divided into fascicle forming Aphanizomenon, solitary Cuspidothrix (type species: Cuspidothrix issatchenkoi (UsAč.) RAJANI. et al. 2005), and some indistinct groups including Aphanizomenon gracile (Lemmerm.) LEMmerm. and so on. The cluster including $U$. natans, Ap. ovalisporum and An. bergii is different from all these clusters including the above mentioned genera or species (Fig. 5). Komárek (2010) revises planktonic nostocacean genera and he includes Ap. ovalisporum and An. bergii in the "Anabaena-like cluster C", but he dose not selected type species and reference strain. The characters of them are as follows; trichome is solitary with narrowed ends and akinetes are distant from heterocytes (KoMÁREK 2010). Umezakia natans M.WATAN. is also considered to be in "Anabaena-like cluster C". Although An. bergii and Ap. ovalisporum may be included in genus 'Umezakia M.WATAN.', we have not enough morphological and molecular information about An. bergii and Ap. ovalisporum. Then it needs future works to decide the relation to other genera and species of Nostocaceae.

\section{Acknowledgements}

We thank Dr. J. Komárek and Dr. E. Zapomělová for discussioning of the manuscript. This study was partially supported by the Collection Building Fellowship of the National Museum of Nature and Science.

\section{References}

Gkelis, S., Moustaka-Gouni, M., Sibonen, K. \& LANARAS, T. (2005): First report of the cyanobacterium Aphanizomenon ovalisporum FORTI in two Greek lakes and cyanotoxin occurrence. - J. Plankton Res. 27:1295-1300.

Gugger, M., Lyra, C., Henriksen, P., Couté, A., Humbert, J.-F., \& Sivonen, K. (2002): Phylogenetic comparison of the cyanobacterial genera Anabaena and Aphanizomenon. - Int. J.
Syst. Evol. Microbiol. 52: 1867-1880.

Harada, K., Ohtani, I., Iwamoto, K., Suzuki, M., Watanabe, M. F., Watanabe, M. \& Terao, K. (1994): Isolation of cylindrospermopsin from a cyanobacterium Umezakia natans and its screening method. - Toxicon 32: 73-84.

IChimura, T. \& Watanabe, M. M. (1977): An axenic clone of Microcystis aeruginosa KüTz. emend. ELENKIN from Lake Kasumigaura. - Bull. Jpn. Soc. Phycol. 25:177-181.

KomÁreK, J. (1958): Die taxonomische Revision der planktischen Blaualgen der Tschechoslowakei. -10-206 pp., Algologische Studien, Academia, Praha.

KomÁReK, J. (2010): Modern revision of planktic nostocacean cyanobacteria: a short revew of genera. - Hydrobiologia 639: 231-243.

KomÁreK, J. \& KomÁrková, J. (2006): Diversity of Aphanizomenon-like cyanobacteria. - Czech Phycology 6: 1-32.

KomÁReK, J. \& KovÁČIK, L. (1989): Trichome structure of four Aphanizomenon taxa (Cyanophyceae) from Czechoslovakia, with notes on the taxonomy and delimitation of the genus. - Pl. Syst. Evol. 164: 47-64.

Lane, D.J., Pace, B., Olsen, G.J., Stahlt, D.A., Sogint, M.L. \& PACE, N.R. (1985): Rapid determination of $16 \mathrm{~S}$ ribosomal RNA sequences for phylogenetic analyses. - Proc. Natl. Acad. Sci. USA 82: 6955-6959.

Pollinger, U., Hadas, O., Yacobi, Y.Z., Zohary, T. \& Berman, T. (1998): Aphanizomenon ovalisporum (FORTI) in Lake Kinneret, Israel. J. Plankton Res. 20: 1321-1339.

Rajaniemi, P. HrouzeK, P., Kaštovská, K., Willame, R., Rantala, A., Hoffmann, L. Komárek, J. \& Sivonen, K. (2005a): Phylogenetic and morphological evaluation of the genera Anabaena, Aphanizomenon, Trichormus and Nostoc (Nostocales, Cyanobacteria). - Int. J. Syst. Evol. Microbiol. 55:11-26.

Rajaniemi, P., Komárek, J., Willame, R., Hrouzek, P., Kaštovská, K., Hoffmann, L. \& Sivonen, K. (2005b): Taxonomic consequences from the combined molecular and phenotype evaluation of selected Anabaena and Aphanizomenon strains. - Algological Studies 117: 371-391.

Stüken, A., Campbell, R. J., Quesada, A., Sukenik, A., DAdheech, P. K. \& Wiedner, C. (2009): Genetic and morphologic characterization of four putative cylindrospermopsin producing species of the cyanobacterial genera Anabaena and Aphanizomenon. - J. Plankton Res. 31: 465-480.

Tamura, K., Dudley, J., Nei, M. \& Kumar, S. (2007): MEGA4: Molecular evolutionary Genetics Analysis (MEGA) software version 4.0. - Mol. Biol. Evol. 24: 1596-1599. 
Tuji, A. \& NiIYAma, Y. (2010): Phylogenetic study by the morphological and molecular analyses of Japanese planktonic Anabaena species. - Bull. Natl. Mus. Nat. Sci., Ser. B. 36: 71-80.

Wacklin, P., Hoffmann, L. \& Komárek, J. (2009): Nomenclatural validation of the genetically revised cyanobacterial genus Dolichospermum (RAlFs ex Bornet et Flahault) comb. nova. Fottea 9: 59-64.

Watanabe, M. (1987): Studies on the planktonic bluegreen algae 2. Umezakia natans gen. et sp. nov. (Stigonemataceae) from the Mikata lakes, Fukui Prefecture. - Bull. Nat. Sci. Mus., Ser. B, 13:81-88.

Watanabe, M. (2007): The freshwater planktonic blue-greens of Japan with photographs and illustrations. - 159 pp., Seibundo-Shinkousha, Tokyo (in Japanese with English descriptions).

Watanabe, M., Niryama, Y. \& Tuji, A. (2004): Studies of planktonic blue-green algae 10. Classification of planktonic Anabaena with coiled trichomes maintained in the National Science Museum, Tokyo. - Bull. Nat. Sci. Mus., Ser. B, 30:135149.
Zapomělová, E., Jezberová, J., Hrouzek, P., Hisem, D., ŘehÂKová, K. \& KomÁrková, J. (2009): Polyphasic characterization of three strains of Anabaena reniformis and Aphanizomenon aphanizomenoides (Cyanobacteria) and their reclassification to Sphaerospermum gen. nov. (incl. Anabaena kisseleviana). - J. Phycol. 45: 1363-1375.

Zapomĕlová, E., Jezberová, J., Hrouzek, P., Hisem, D., Řeháková, K. \& Komárková, J.(2010): Polyphasic characterisation of three strains of Anabaena reniformis and Aphanizomenon aphanizomenoides (Cyanobacteria) and their reclasification to Sphaerospermum gen. nov. (incl. Anabaena kisseleviana) (45: 1363-1373). Nomenclatural note. - J. Phycol. 46: 415

(C) Czech Phycological Society (2011)

Recieved Sept 2010

Accepted Dec 2010 